\title{
A new species of amphipod crustacean, Pleusymtes comitari sp nov, associated with gorgonians on deep-water coral reefs off Ireland
}

Myers, AA

http://hdl.handle.net/10026.1/1460

10.1017/S0025315404010367h

Journal of the Marine Biological Association of the United Kingdom

Cambridge University Press (CUP)

All content in PEARL is protected by copyright law. Author manuscripts are made available in accordance with publisher policies. Please cite only the published version using the details provided on the item record or document. In the absence of an open licence (e.g. Creative Commons), permissions for further reuse of content should be sought from the publisher or author. 


\title{
A new species of amphipod crustacean, Pleusymtes comitari sp. nov., associated with gorgonians on deep-water coral reefs off Ireland
}

\author{
A.A. Myers* ${ }^{\ddagger}$ and J.M. Hall-Spencer ${ }^{\dagger}$ \\ *Department of Zoology, Ecology and Plant Science, National University of Ireland Cork, Lee Maltings, Prospect Row, Cork, Ireland. \\ ${ }^{\dagger}$ Marine Biology and Ecology Research Group, Department of Biological Sciences, University of Plymouth, Plymouth, PL4 8AA, UK. \\ ${ }^{\ddagger}$ Corresponding author, e-mail: alanmyers@crustacea.net
}

\begin{abstract}
A new species of pleustid amphipod of the genus Pleusymtes is described from the west coast of Ireland. It was found to be common in association with an Acanthogorgia sp. gorgonian at 725 and $900 \mathrm{~m}$ depth on coral habitats in the continental shelf-break areas of the Porcupine Seabight and Porcupine Bank. It is assumed to be a commensal due to its modified pereopod dactyls.
\end{abstract}

\section{INTRODUCTION}

The pioneering expeditions of HMS Porcupine showed that deep-water habitats off SW Ireland support high concentrations of corals (Duncan, 1873). Subsequent dredging surveys, such as those reported by Le Danois (1948), confirmed that scleractinians (e.g. Madrepora oculata, Lophelia pertusa and Desmophyllum critagalli) were widespread at the continental shelf-break in an area that had become known as the Porcupine Bank. Recently, commercial interests in offshore hydrocarbons have led to geological studies of oil reserves in the area (Spencer \& MacTiernan, 2001) with detailed geophysical surveys showing substantial coral-rich carbonate mounds (De Mol et al., 2002; Huvenne et al., 2002), which rise up to $300 \mathrm{~m}$ above the seabed and can measure up to a few $\mathrm{km}$ across.

It is against this background that an international expedition was mounted in 2003 using RV Polarstern as a platform for the IFREMER-owned remote operated vehicle VICTOR (cruise ARK-XIX/3a). Part of this expedition involved mapping and collecting some of the largest and most obvious sessile organisms associated with the coral habitat, including hard corals (scleractinians), black corals (antipatharians), hydrocorals (stylasterids) and sea fans (gorgonians). The commonest gorgonian present on the mounds was an Acanthogorgia sp. which was collected in a box core (PS64/271-1) from the 'Thérèse Mound' at $51^{\circ} 25.75^{\prime} \mathrm{N} 11^{\circ} 46.18^{\prime} \mathrm{W}$ (Porcupine Bight) at $900 \mathrm{~m}$ depth on 9 June 2003 and from the 'Twin Mounds' using the ROV manipulator arm at $53.08^{\circ} 995^{\prime} \mathrm{N}$ $14.82^{\circ} 335^{\prime} \mathrm{W}$ (Porcupine Bank) at $730 \mathrm{~m}$ depth on 12 June 2003.

A number of amphipods clung to the surfaces of each of the Acanthogorgia sp. collected, most of which were known species and occurred in very small numbers. One species, however, which was common and showed morphological adaptation for holding onto the gorgonian, proved to be an undescribed species of Pleusymtes Barnard, 1969.
The genus Pleusymtes is restricted to the northern hemisphere, occurring in both the Atlantic and the Pacific oceans. Currently 22 species of the genus are known, of which seven have been described from the North Atlantic and Arctic oceans. These are P. glabra (Boeck, 1861), from the north east boreal Atlantic; P. kariana (Stappers, 1911), P. karsteni Barnard, 1959, P. margulisae Tvetkova \& Golikov, 1990 and P. pulchella (Sars, 1876) from the Arctic basin; and P. buttoni Dunbar, 1954 and P. glabroides Dunbar, 1954, from the North west Atlantic. A further Atlantic species is described here, $P$. comitari sp. nov, which is currently known only from deep water off the West coast of Ireland. It appears to be a commensal with Acanthogorgia sp., having pereopod dactyls which are clearly modified for secure gripping of the gorgonian host.

\section{MATERIALS AND METHODS}

Material upon which this study was based was collected during 2003 using RV Polarstern as a platform for the IFREMER-owned remote operated vehicle VICTOR (cruise ARK-XIX/3a). Specimens were dissected and mounted in faure's liquid prior to examination under a Nemarski phase-contrast compound microscope.

\section{SYSTEMATICS}

Order AMPHIPODA Latreille, 1816

Suborder Gammaridea Latreille, 1803

Family Pleustidae Buchholz, 1874

Genus Pleusymtes Barnard, 1969

Pleusymtes comitari sp. nov.

(Figures 1-3)

\section{Material examined}

Holotype: female, $4.5 \mathrm{~mm}$, NMI 37.2004 'Twin Mounds', $53.08^{\circ} 995^{\prime} \mathrm{N} 14.82^{\circ} 335^{\prime} \mathrm{W}$ (Porcupine Bank), $730 \mathrm{~m}$ depth, 12 June 2003. ROV. J.M. Hall-Spencer. 


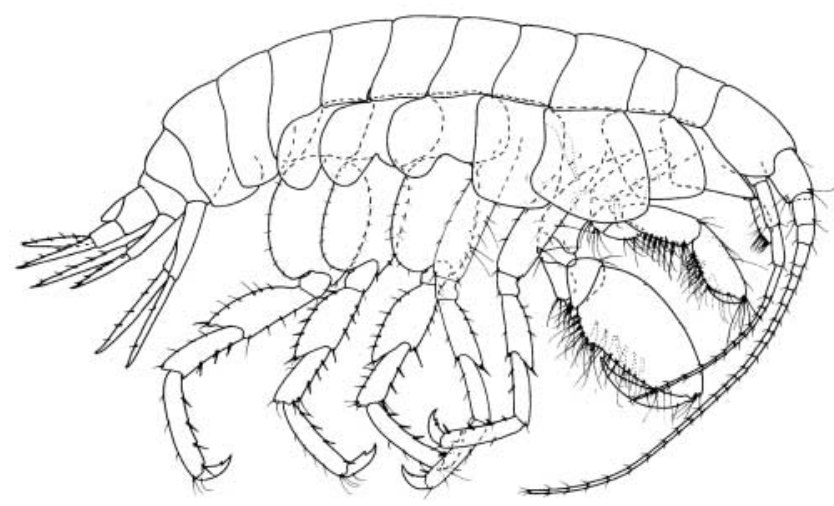

Figure 1. Pleusymtes comitari sp. nov., female holotype. 'Twin mounds', Porcupine Bank, Western Ireland U3 enlarged $2 \times$ other uropods.

Paratypes: 13 males, 13 females and 18 juveniles, NMI 38.2004, same data as holotype.

\section{Diagnosis}

Pleusymtes with coxa 1 strongly anteriorally produced. Gnathopods 1 and 2 strongly dimporphic. Spines on the dactyls of pereopods 3-7. Telson incised.

\section{Description}

No significant sexual dimorphism. Head with rostrum weakly developed, eyes absent. Body lacking dorsal teeth, humps or carinae. Antenna 1 a little over half length of body, peduncular articles short, article 1 lacking a distal process, article 2 about two thirds length of article 1; flagellum with 23 articles; accessory flagellum obsolescent. Antenna 2 two-thirds length of antenna 1. Mandibular molar large and triturative; palp three articulate, article 3 longer than article 2. Maxilla 1 normal, inner plate bearing two stout setae. Maxilla 2 normal. Labium inner plates coalesced, mandibular processes short. Maxilliped inner and outer plates short; palp 4-articulate powerful, article 3 without distal tubercle, dactylus well developed, longer than article 3 and with a distal nail. Gnathopod 1 coxa greatly extended forwards such that its width exceeds its length, anteriorally sub-acute, carpus and propodus slender, subequal in length. Gnathopod 2 coxa subsquare, basis with strongly developed flange on antero-distal margin, ischium also with flange on anterior margin, carpus very short, cup-shaped, propodus massive, subovoid, almost twice as long as broad, posterior margin weakly convex, palm delimited by a protrusion of the posterior margin carrying a robust seta, dactylus strong, elongate, fitting palm. Pereopods 3-4 similar, of normal pleustid form, but dactyls with two spines on the posterior margin. Pereopods 5-7 similar to each other, of usual pleustid form, but basis subrectangular in pereopods 5-6, subovoid in pereopod 7, posterior margin of dactyl in pereopods 5-7, with 1-2 strong spines. Epimera 1-2 rounded. Epimeron 3 posterior margin weakly subquadrate. Uropods 1-3 both rami lacking distal setae but with a few marginal setae. Uropod 1 rami subequal to peduncle, slender. Uropod 2 rami of unequal length, inner ramus much longer than peduncle, outer ramus subequal in length with peduncle, Uropod 3 rami weakly unequal. Telson rounded, incised distally.

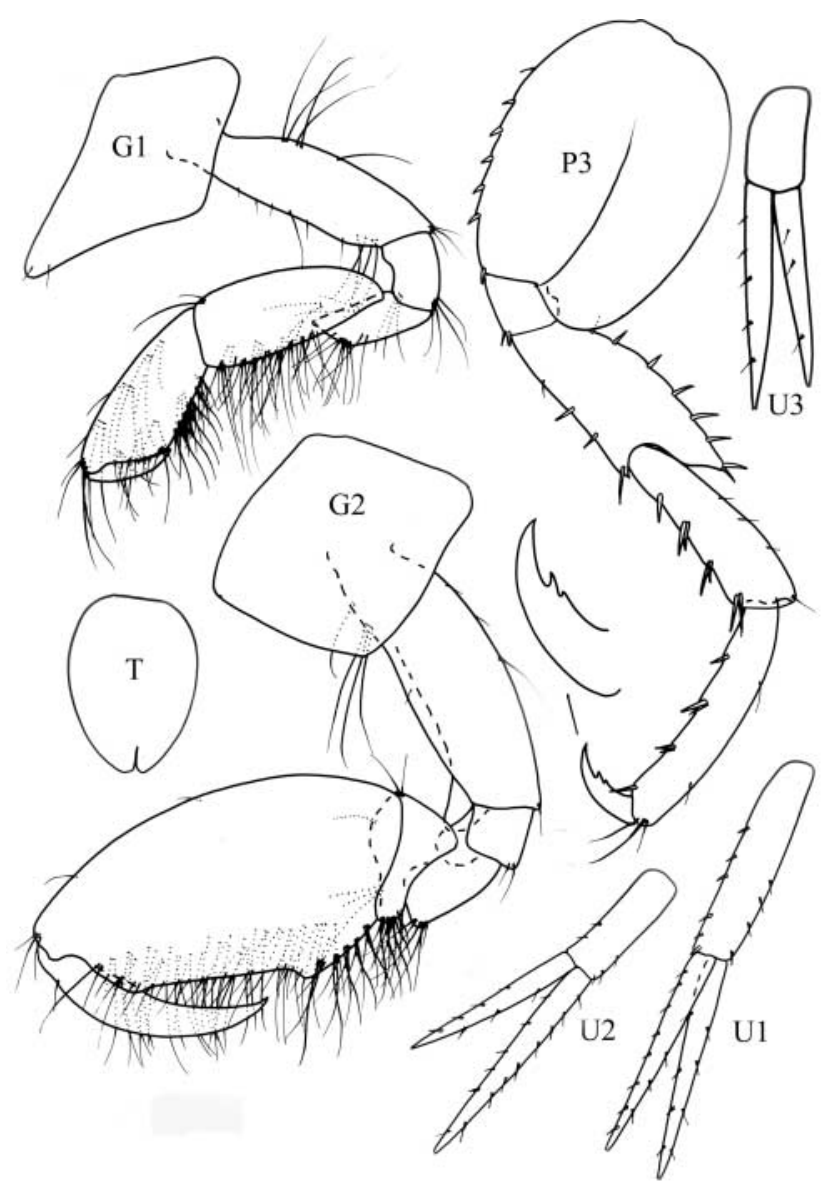

Figure 2. Pleusymtes comitari sp. nov., female holotype. 'Twin mounds', Porcupine Bank, Western Ireland. G1, G2, gnathopods 1 and 2; P3, pereopod 3; T, telson; U1, U2, U3, uropods $1-3$.

\section{Remarks}

Pleusymtes comitari sp. nov.differs from all other species described in this genus by the presence of spines on the dactyls of pereopods 3-7 and by its strongly anteriorally produced coxa 1. In its very dimorphic gnathopods 1 and 2, it differs from $P$. symbiotica Gamo \& Shinpo, 1992 (also a gorgonian commensal), P. glaber (Boeck, 1861), P. kariana (Stappers, 1911), P. karsteni (Barnard, 1959), P. uncigera (Gurjanova, 1938), and P. margulisae Tzvetkova \& Golikov, 1990, all of which have only weakly dimorphic gnathopods. A sub-acute, forward-produced coxa 1 also occurs in P. suberitobius Gurjanova, 1951, but that species has very unequal uropod 3 rami and lacks spines on the dactylus of pereopods 3-7. In having the rami of uropod 1 subequal in length this species resembles $P$. coquilla Barnard, 1971, from Oregon, but differs from that species in lacking a ventral spine on article 1 of antenna 1 as well as in its spiny dactyls of pereopods 3-7.

In having spines on the posterior margin of the dactyli, this species resembles Dactylopleustes echinoicus (Tzvetkova, 1975), from the Commander Islands near the Bering Strait, but that genus differs from Pleusymtes in its feeble, poorly triturative, molar. Interestingly $D$. echinoicus is known to be a commensal of Strongylocentrotus polyacanthus. $P$. comitari differs from all other known species in the genus in having the telson incised to nearly one fifth its length. In all other species the telson is entire, being rounded or truncate. In the family Pleustidae, only Cleonardopsis K.H. 


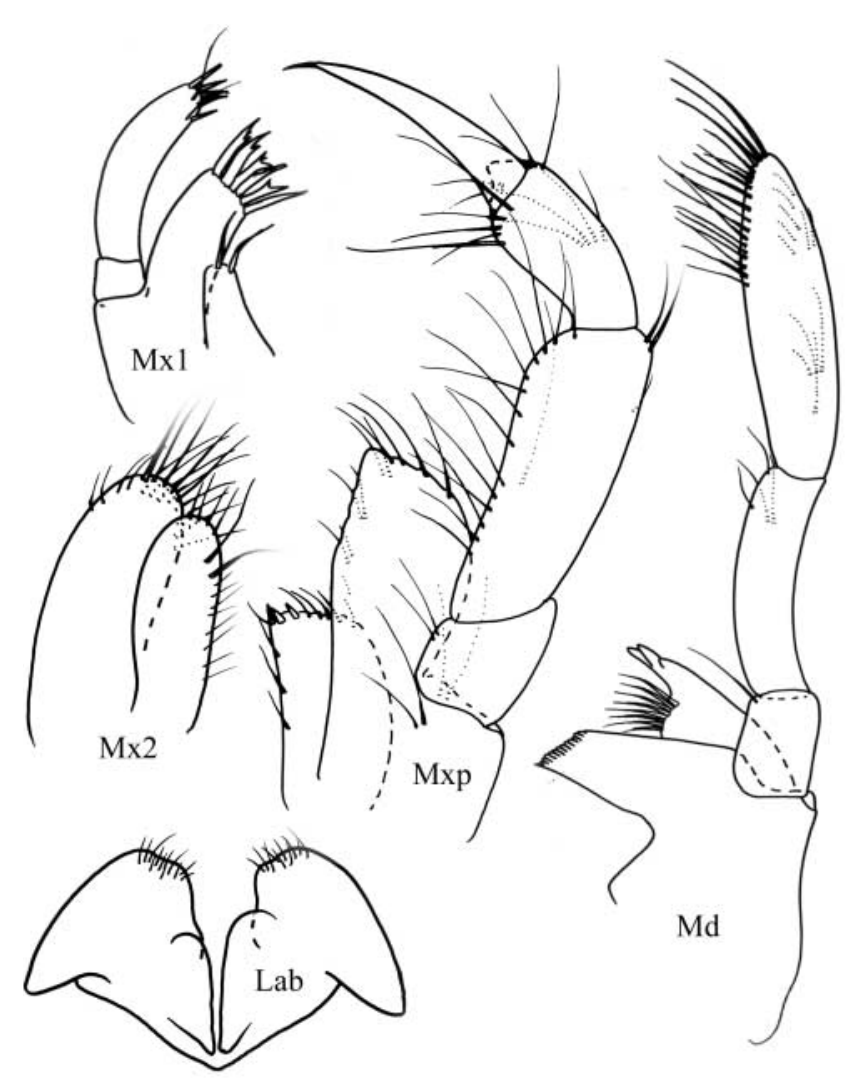

Figure 3. Pleusymtes comitari sp. nov., female holotype. 'Twin mounds', Porcupine Bank, Western Ireland. Lab, labium; Md, mandible; Mxp, maxilliped; Mx1, Mx2, maxilla 1 and 2.

Barnard, has a similarly incised telson. All species in that genus, however, differ from P. comitari in their keeled body, well developed accessory flagellum (one long article), equal sized gnathopod 1 and 2, and unornamented dactyls of pereopods $3-7$.

\section{Ecology}

Although the amphipods were too small to be seen in situ with the ROV, they were abundant and easily visible to the naked eye on Acanthogorgia sp. collected in June 2003 at water depths of $725 \mathrm{~m}$ (water temperature $8.9^{\circ} \mathrm{C}$, salinity $35.30 \mathrm{psu}$ ) and $900 \mathrm{~m}$ (water temperature $9.5^{\circ} \mathrm{C}$, salinity $35.55 \mathrm{psu}$ ). The gorgonians were quickly transferred, along with their associated fauna, into aquaria for observations aboard RV Polarstern. The $P$. comitari were the same orange colour as their host (which turned dark brown in alcohol) and clung to the surface of the gorgonian coenenchyme. They crawled up and down the branches, rarely swimming from branch to branch unless disturbed. Although the aquaria were maintained at $10^{\circ} \mathrm{C}$, most of the amphipods were found dead and trapped in the surface meniscus of the aquaria within $24 \mathrm{~h}$. Acanthogorgia sp. was the commonest gorgonian recorded in 88 hours of VICTOR surveys of the living coral mounds at depths of $500-1000 \mathrm{~m}$ in the Porcupine Seabight and on the Porcupine Bank.

\section{Etymology}

From the latin 'comitari' meaning 'to accompany' alluding to its association with the gorgonian Acanthogorgia sp.

\section{DISCUSSION}

Pleusymtes comitari was collected only on Acanthogorgia sp., where it was common. The species of Acanthogorgia has not yet been determined with certainty, although Le Danois (1948) recorded A. muricata as characteristic of the deepwater coral habitats off Ireland.

The toothed dactyls of $P$. comitari appear to be an adaptation for gripping, suggesting that it may be an obligate commensal on the gorgonian. In addition to P. comitari sp. nov. and $P$. symbiotica Gamo \& Shinpo, both associated with gorgonians, other pleustid amphipods also suspected of being commensal include Pleusymtes subglaber with the ophiuroid Amphiodia urtica and the previously mentioned Dactylopleustes echinoicus with the echinoid Strongylocentrotus polyacanthus.

This study adds to several others that show intricate relationships between crustaceans and gorgonians worldwide. Examples include copepods (Acanthomolgus sp.) that associate with the gorgonian Acanthogorgia aspera off Bermuda (Humes, 1973), barnacles (Canopea calceol) which grow embedded in the coenosarc of gorgonians off Pakistan (Kazmi, 2001) and pontoniine shrimps that live on a variety of gorgonian species worldwide (Bruce, 1998). In descriptions of the pontoniine Pseudocoutieri wirtzi, d'Udekem-d'Acoz (2001) shows that their colour blends in with their gorgonian host (Leptogorgia gainii) and that their last three pairs of pereopods are adapted to allow the shrimps to lay flat as they grasp the gorgonian. Cantera et al. (1987) describe the morphological, physiological and ethological cryptic adaptations of several crustacean species which live in association with the gorgonian Lophogorgia alba. Kumagai \& Aoki (2003) show that Pleusymtes symbiotica Gamo \& Shinpo, which is host-specific to melithaeid gorgonians, dominates their epifaunal community year-round at shallow depths off southern Japan. Most studies of gorgonian associates have been carried out in shallow water due to the expense and difficulty of deepsea research. Recent work using an ROV-mounted suction-sampler has shown that a rich crustacean fauna lives in association with gorgonians at 300-500 m depth off Nova Scotia, including parasitic copepods that are probably obligate associates (Buhl-Mortensen \& Mortensen, 2004). Non parasitic crustaceans that associate with alcyonaceans probably take advantage of their elevated position in the water current and hide amongst the predatory polyps of their host, some may even take food from the polyps or collect skeins of mucus in which detritus and debris are trapped (Morton, 1988).

Despite our knowing of the existence of cold-water corals since the times of Linnaeus, it is only in recent years that we have begun to unravel the geological and ecological complexities of the astonishing biogenic reefs formed by deep-water corals at high latitudes (Freiwald et al., 2002; Roberts et al., 2003). The present study shows that these habitats may harbour a treasure-trove of intricate interactions between undescribed species and increases our concern that unregulated trawling remains a major threat to these habitats (Hall-Spencer et al., 2002).

ROV footage is courtesy and copyright of IFREMER and was collected using IFREMER's VICTOR6000. Data was collected onboard the RV Polarstern on the Alfred Wegener Institute coordinated cruise ARK XIX-3a. We would like to thank all 
members of the expedition, plus those people behind the scenes at the organising institutes for their generous help throughout. JH-S was funded by a Royal Society University Research Fellowship.

\section{REFERENCES}

Barnard, J.L., 1959. Epipelagic and under-ice Amphipoda of the Central Arctic Basin. Scientific Studies at Fletcher's Ice Island, T-3, 1952-55, Vol. 1. Geophysical Research Papers, 63, 115-152.

Barnard, J.L., 1969. A biological survey of Bahía de los Angeles, Gulf of California, Mexico. IV. Benthic Amphipoda (Crustacea). Transactions of the San Diego Society of Natural History, 15, 175-228.

Barnard, J.L., 1971. Gammaridean Amphipoda from a deepsea transect off Oregon. Smithsonian Contributions to Zoology, 61, $1-86$.

Boeck, A., 1861. Bemaerkninger angaaende de ved de norske kyster forekommende Amphipoder. Forhandlinger ved de Skandinaviske Naturforskeres Mfte, 8, 631-677.

Bruce, A.L., 1998. A second species of the genus Balssia Kemp, 1922 (Crustacea, Decapoda, Pontoniinae). Zoosystema, 20, 603-611.

Buhl-Mortensen, L. \& Mortensen, P.B., 2004. Crustaceans associated with the deep water gorgonian corals Paragorgia arborea (L., 1978) and Primnoa resedaeformis (Gunn., 1763). Journal of Natural History, 38, 1233-1247.

Cantera, J.R., Von Prahl, H. \& Neira, O.R., 1987. Molluscs, crustaceans and echinoderms associated to the Gorgonid (Lophogorgia alba) Duchassaing and Michelotti, 1864, in Gorgona Island. Boletin ecotropica. Bogota, 17, 3-23.

De Mol, B. et al., 2002. Large deep-water coral banks in the Porcupine Basin, southwest of Ireland. Marine Geology, 188, 193-231.

Dunbar, M.J., 1954. The amphipod Crustacea of Ungava Bay, Canadian eastern Arctic. Fournal of the Fisheries Research Board of Canada, 11 (6), 709-798.

Duncan, P.M., 1873. A description of the Madreporaria dredged up during the Expeditions of HMS 'Porcupine' in 1869 and 1870. Transactions of the Zoological Society of London, 8, 303-344 +11 Plates.

Freiwald, A., Hûhnerbach, V., Lindberg, B., Wilson, J.B. \& Campbell, J., 2002. The Sula Reef Complex, Norwegian Shelf. Facies, 47, 179-200.

Gamo, S. \& Shinpo, Y., 1992. A new gammaridean amphipod Pleusymtes symbiotica ectosymbiotic with a Japanese gorgonacean octocoral, Melithaea flabellifera (Kukenthal) from Sagami Bay. Science Reports of the Yokohama National University, Sec 2, 39, 1-11.

Gurjanova, E., 1938. Amphipoda, Gammaroidea of Siaukhu Bay and Sudzukhe Bay (Japan Sea). Reports of the Japan Sea Hydrobiological Expedition of the Zoological Institute of the Academy of Sciences USSR in 1934, 1, 241-404.
Gurjanova, E.F., 1951. Amphipods of the seas of the USSR and surrounding waters (Amphipoda-Gammaridea). Akademiya Nauk SSSR, Opredeliteli po Faune SSSR, 41, 1-1029.

Hall-Spencer, J.M., Allain, V. \& Fossa, J.H., 2002. Trawling damage to Northeast Atlantic ancient coral reefs. Proceedings of the Royal Society, B, 269, 507-511.

Humes, A.G., 1973. Cyclopoid copepods of the genus Acanthomolgus (Lichomolgidae) associated with gorganians in Bermuda. Journal of Natural History, 7, 85-115.

Huvenne, V., Blondel, P. \& Henriet, J.-P., 2002. Textural analyses of sidescan sonar imagery from two mound provinces in the Porcupine Seabight. Marine Geology, 3190, 1-19.

Kazmi, Q.B., 2001. Report of Conopea calceola (Ellis, 1758) Cirripedia, Balanomorpha, Archaeobalanidae) from Karachi waters. Pakistan Fournal of Marine Sciences, 10, 73-77.

Kumagai, N.H. \& Aoki, M.N., 2003. Seasonal changes in the epifaunal community on the shallow-water gorgonian Melithaea flabellifera. Fournal of the Marine Biological Association of the United Kingdom, 83, 1221-1222.

Le Danois, E., 1948. Les Profondeurs de la Mer. Paris: Payot.

Morton, B., 1988. Partnerships in the sea. Hong Kong: Hong Kong University Press.

Roberts, J.M., Long, D., Wilson, J.B., Mortensen, P.B. \& Gage, J.D., 2003. The cold-water coral Lophelia pertusa (Scleractinia) and enigmatic seabed mounds along the north-east Atlantic margin: are they related? Marine Pollution Bulletin, 46, 7-20.

Sars, G.O., 1876. Prodromus descriptionis crustaceorum ft [sic] pycnogonidarum, qvae in expeditione Norvegica anno 1876, observavit. Archiv for Mathematik og Naturvidenskab, 2, 337-371.

Spencer, A.M. \& MacTiernan, B., 2001. Petroleum systems offshore western Ireland in an Atlantic margin context. In The petroleum exploration of Ireland's offshore basins (ed. P.M. Shannon et al.), pp. 411-438. Geological Society of London, Special Publication no. 188.

Stappers, L., 1911. Crustacés Malacostraces. Duc d'Orleans, Campagne Arctique de 1907. Bruxelles, 1-152.

Tzvetkova, N.L., 1975. A new species of Pleustidae (Amphipoda), a commensal of sea urchins, from the Commander Islands. Zoologichesky Zhurnal, 54, 121-124.

Tzvetkova, N.L. \& Golikov, A.A., 1990. Fauna, ecology and role in ecosystems of amphipods (Amphipoda, Gammaridea) at the new Siberian Shoals and adjacent waters of the Laptev sea. Akademiya Nauk SSSR, Issledovaniya Fauny Morei, 37(45), 258-343.

Udekem-d'Acoz, C. d', 2001. Description of Pseudocoutierea wirtzi a new cnidarian-associated pontoniine shrimp from Cape Verde islands, with decalcified meral swellings in walking legs. Bulletin de l'Institute de Recherche et Science Naturelle Belgique, 70, 69-90. 